\title{
STUDIES ON CONCRETE BY PARTIAL REPLACEMENT OF CEMENT WITH VOLCANIC ASH
}

\author{
Rika Deni Susanti ${ }^{1 *}$ Ramlan Tambunan ${ }^{1}$ Aazokhi Waruwu ${ }^{1}$ Munajat Syamsuddin ${ }^{2}$ \\ ${ }^{1}$ Department of Civil Engineering, Institut Teknologi Medan, Indonesia \\ ${ }^{2}$ Faculty of Economics, Medan State University, Indonesia
}

This paper presents the study on the volcanic ash as replacement of cement on compression strength of concrete. Preliminary study at the early stage were conducted with the specific gravity and sieve analysis of the volcanic as replacement of cement material of concrete. The cement replacement is made with the weight of the volcanic ash in the cement ratio of $2 \%, 4 \%, 6 \%$, and $8 \%$. Compressive strength test of concrete was conducted at the age of 7,14 , and 28 days. The mechanical properties by applying slump value and compressive strength were investigated. The result showed that compression strength value of concrete with volcanic ash are close to the same with the normal concrete mix design. The addition of volcanic ash shows improvement of compression strength of concrete.

Key words: Cementation, Ashes, Volcanics, Strengths, Concrete, Compressive strength

\section{INTRODUCTION}

The development of construction materials is progressing rapidly. Generally the materials used are locally accessible and environmentally friendly materials. Lately a lot of research on the use of volcanic ash, fly ash, and coal ash base as a mixture of concrete and as a material improvement of the soil. Improvement of soil with volcanic ash in order to increase the bearing capacity of the subgrade [04], [08], [09]. In addition to soil improvement, other soil reinforcement also progressed relatively rapidly, including the use of bamboo as a soil reinforcement material and a nailed slab-system for reinforcement for road construction [10], [11], [13].

Recycled concrete is a relatively new technology in the production of concrete, and as such it requires careful approach. Recycling of this material, which is the symbol of construction today, it becomes not only technical innovation, but also the needs of modern urban society. [12]. Concrete is a mixture of portland cement with coarse aggregate, fine aggregate, water, and added admixture that will form fresh concrete. Concrete hardening will soon occur due to the bonding event between water and cement, where the mass of the concrete will grow stronger as the age of concrete.

Normal concrete has a disadvantage, so many experts or concrete experts find admixture, and additives with various functions aimed at masking or reducing concrete weaknesses. Concrete preparation can be done by mixing fine aggregate, coarse aggregate, portland cement, water, and added ingredients.

Added materials used can be divided into two mineral additive or chemical as admixture. Additional materials that can replace the function of cement as a binder can use volcanic ash.

Indonesia region which has approximately 83 active volcanoes are a source of wealth of this region. The last five years, active volcanoes in Indonesia, Mount Merapi, Kelud and Sinabung eruption issuing experiencing the abundant material [09]. Volcanic material is a mineral volcanic rock including glass material that has the size of sand and gravel with a diameter of approximately of $2 \mathrm{~mm}$. Volcanic ash particles are very small, generally can have a cross section smaller than $0.001 \mathrm{~mm}$. Bromo's Volcanic Ash can be characteristic as a cement replacement material. It can not only mitigate social and environmental problems but olso improve concrete properties [01]. The addition of volcanic ash and lime affects soil compactness, i.e., increased maximum dry volume weight and decreased optimum water content. The stabilization soil strength improvement can be seen in the increased un-soaked and soaked CBR values. Such change occurs due to the pozzolanic reaction between volcanic ash and lime and clay soil that results in mixed inter-particle bonding, making sand stronger and more rigid. It can be observed in SEM test that the clay particle clumps into the greater particle. Subgrade soil with a low CBR value can be improved by adding of volcanic ash and lime [08].

The compressive strength generally increase with curing period and decreases with increasing percentages replacement from material of shea nut shell ash, rice husk ash, and corn cob ash [02]. The compressive strength also decreased with increase in laterite content, the strength of the laterized concrete however increases as the curing age progresses [03]. The 28-day, density dropped from $2390 \mathrm{~kg} / \mathrm{m}^{3}$ to $2285 \mathrm{~kg} / \mathrm{m}^{3}$ (i.e. $4.4 \%$ loss) and the compressive strength from $25.08 \mathrm{~N} / \mathrm{mm} 2$ to $17.98 \mathrm{~N} / \mathrm{mm}^{2}$ (i.e. $28 \%$ loss) for $0-30 \%$ variation of VA content with no laterite introduced.

Apart from being a concrete mixture, volcanic ash can also be used for a mixture of soil improvements. The optimum mix to obtain a low plasticity index value is to add volcanic ash $20 \%, 22 \%, 25 \%, 27 \%$. The addition volcanic 
ash and limestone, lead to soil particles easily detached from the bond [04]. Another material as a substitute for cement were alccofine and fine fly ash. The addition of alccofine shows an early strength gaining property and is ecofriendly to nature and that of fly ash shows improvement in long term mechanical properties [05]. The relative cost of alccofine is cheaper than cement hence it is also economic in producing higher strength. Silica fume of $5 \%$ and fly ash of $30 \%$ mixes showed highest compressive strength as compared to the control mix. Whereas all CRM mixes resulted in high flexural strength, which was due to the negligible bleeding and high cohesiveness [06]. The performance of MIRHA to replace the cement depends on the burning degree which will affect the microstructure of the binder. To improve compression strength of concrete can be done with replacement of fine aggregate with pond ash, by partially replacing sand with pond ash, a noticeable decrease in compressive strength is found in accordance with the increasing of a percentage of the pond ash. Effect of addition of pond ash in the concrete mixture causes a decrease in the compressive strength of concrete et the age of $1,3,7$, 14,28 , and 90 days [07]. It is recommended that the use of waste coal ash mixed with sand for the manufacture of concrete is not used on a large construction or heavy loading structures.

Volcanic ash has a smaller density than cement. Thus the resulting concrete will be lighter, this will be better for concrete construction. Volcanic ash can be used as a substitute for cement for concrete mixture. In this paper, we will describe the change in the compressive strength of concrete due to changes in cement composition as a concrete binder. A review is conducted on volcanic ash as a cement replacement material in a particular composition and comparing it to normal concrete.

\section{RESEARCH METHODS}

The study was conducted using volcanic ash from Sinabung of North Sumatra. Tests conducted at the preliminary research stage are specific gravity, seive analysis, and slump test. Further tests were performed with concrete compressive strength test with $0 \%, 2 \%, 4 \%, 6 \%$, and $8 \%$ of volcanic ash each with concrete age of 7,14 , and 28 days. The specimen was tested after soaked in water for 7,14 , and 28 days.

From each test scheme, it was found that the potential of concrete quality was achieved when volcanic ash was replaced by cement. From each test scheme get compressive strength value of concrete. From the compressive strength of concrete with the percentage of volcanic ash, there is a significant value of concrete compressive strength with normal concrete without the addition of this alternative material.

\section{RESULTS AND DISCUSSION}

\section{Results of Slump Test}

Figure 1 shows the percentage relationship of volcanic ash with slump test value. The slump value increased for the composition of volcanic ash $4 \%$, while above $4 \%$ slump value decreased. The slump test is performed for each mixture in both the normal and concrete mix concrete which is made with a mixture of volcanic ash as a cement replacement material in a concrete mixture. From the slump test, it was found that the normal concrete mixture had better workability than the concrete mixture which used the combination of Sinabung's Volcano as a cement substitution material with the same moisture content. The cause of the high level of viscosity of concrete with the combination of Sinabung's volcanic ash is due to the high water absorption capacity of the volcanic ash when stirred in dry and dusty conditions.

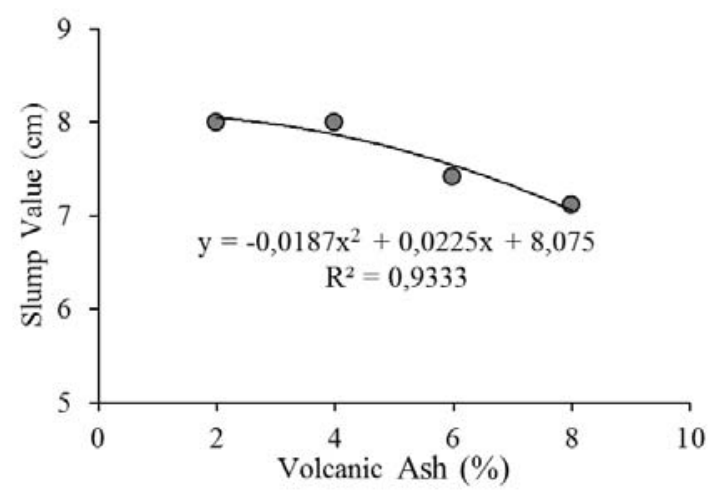

Figure 1: Relationship of slump value and volcanic ash

\section{Results of Compression Strength of Normal Concrete}

Testing of concrete press load in this experiment using cube-shaped specimen with size $15 \mathrm{~cm} \times 15 \mathrm{~cm} \times 15$ $\mathrm{cm}$. The concrete press load of the specimen is obtained from the average compressive strength value, taken at the age of the test specimen 7, 14, and 28 days. Furthermore the test results are grouped according to the type of each test specimen that will make comparison of the results as Table 1.

Table 1: Compression strength of normal concrete

\begin{tabular}{|c|c|c|c|}
\hline \multirow{2}{*}{ No } & \multicolumn{4}{|c|}{ Compression Strength of Normal Concrete } \\
\cline { 2 - 4 } & 7 days & 14 days & 28 days \\
\hline 1 & 20 & 23.5 & 23.1 \\
\hline 2 & 20.6 & 22.8 & 20.4 \\
\hline 3 & 18.6 & 22.2 & 19.7 \\
\hline Average & 19.73 & 22.83 & 22.83 \\
\hline
\end{tabular}


Based on Table 1 it can be concluded that the normal compressive strength of concrete with normal mixture yields a higher average compressive strength of the plan quality of $20 \mathrm{MPa}$ at the age of the test object 28 days. From the above table can be described time history or travel process of concrete binding of the early binding time of 7 days until the concrete was perfect boost at the age of 28 days as in Figure 2.

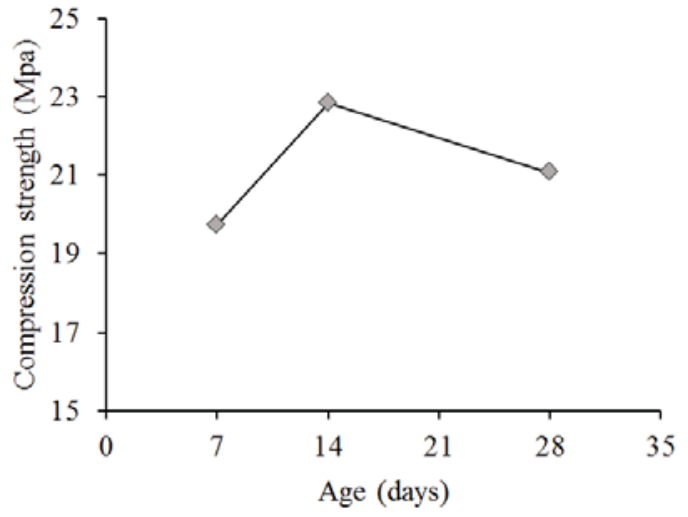

Figure 2: Relationship of age and compression strength of normal concrete

\section{Results of Compression Strength with Volcano Ash}

The relationship of concrete age and compression strength of concrete from test result for all test schemes can be seen in Figure 3. Compressive strength test of concrete using cube-shaped specimen with size $15 \mathrm{~cm}$ $\times 15 \mathrm{~cm} \times 15 \mathrm{~cm}$. The concrete press load of the specimen is obtained from the average compressive strength values taken at the test object age, 7,14 , and 28 days. Furthermore, the test results are grouped according to the type of each specimen that will make the comparison of the result. From this research can be seen that the results obtained on concrete compressive strength test with the addition of volcanic ash of $2 \%, 4 \%, 6 \%$, and $8 \%$ on each object yield different compressive strength, which with the addition of Sinabung's volcanic ash of $4 \%$ produces the compressive strength of concrete near the normal concrete.

The results obtained in the concrete compressive load test with the substitute of cement with Sinabung volcanic ash of $2 \%, 4 \%, 6 \%, 8 \%$ in each age, are mixed into the concrete with the same job mix yielding different compressive strength, whereas replacement of cement with volcanic ash produces a lower concrete compression load than normal concrete for the life of concrete below 14 days, while for 28 days concrete time yields higher compressive strength value than normal concrete in concrete mixture with $2 \%$ and $4 \%$ of volcanic ash. Likewise, the addition of $6 \%$ and $8 \%$ volcanic ash yielded concrete compressive strength values close to equal to the compressive strength of normal concrete. Thus it can be stated that volcanic ash has the potential to replace part of the amount of cement in the concrete mixture.

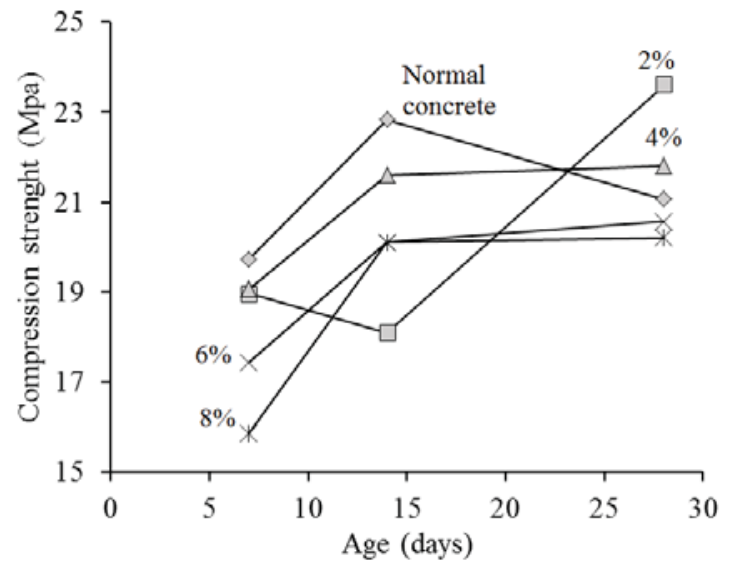

Figure 3: Relationship of age and compression strength of concrete with volcanic ash

\section{Effect of Volcanic toward Compression Strength}

Effect of volcanic toward compression strength of concrete can be seen in Figure 4. Generally, the value of concrete compressive strength increases for the addition of volcanic ash below $4 \%$, but above $4 \%$ concrete strength value tends to be constant except for 7 days concrete age. The compressive strength of the concrete at 14 days and 28 days is constant in addition to above $4 \%$ and not so much different from the normal compressive strength value. The use of volcanic ash as a substitute for cement can be considered for concrete mixtures because in addition to cheaper prices, it can also solve environmental problems. When viewed in terms of strength, concrete with volcanic ash produces a compressive strength value that is still higher than the compressive strength of concrete plans (Table 2).

Values obtained in concrete load experiment on both normal and concrete concrete using volcanic ash as cementitious substitution material with composition of $2 \%$, $4 \%, 6 \%$, and $8 \%$ according to the age of the specimens showed that the addition of volcanic ash to the job mix Similarly, it produces a varying strength of concrete, but generally produces lower pressure load capability than normal concrete. The greater percentage of the addition of volcanic ash as a cement substitution at the job mix will result in the ability of concrete to bear the lower press load. But the concrete carrying capacity of the concrete compressive load with the Volcanic ash as the Cement Substitution yields a higher capability than the planned press load of $20 \mathrm{MPa}$ (Table 2).

The composition of volcanic ash below $4 \%$ is of particular concern, since in addition to the good effect on the compressive strength of the concrete also provides a good increase in the slump value as in Figure 1. 


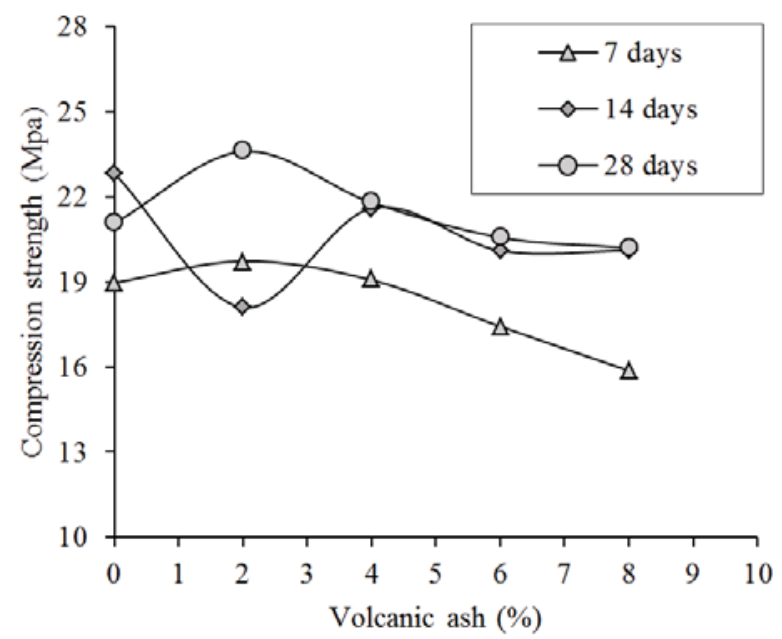

Figure 4: Relationship of \% volcanic ash and compression strength of concrete

Particularly for the 28-day concrete strength, the value of concrete compressive strength shows a significant increase and exceeds strong Concrete press required 20 $\mathrm{MPa}$, therefore the recommended amount of volcanic ash composition if using volcanic ash of Mount Sinabung is between $2 \%$ and $4 \%$.

Table 2: Compression strength of concrete with volcanic ash

\begin{tabular}{|c|c|c|c|}
\hline $\begin{array}{c}\text { Volcanic } \\
\text { ash (\%) } \\
(\%)\end{array}$ & $\begin{array}{c}\text { Result of } \\
\text { compression } \\
\text { strength } \\
(\mathrm{Mpa})\end{array}$ & $\begin{array}{c}\text { Standard of } \\
\text { compression } \\
\text { strength } \\
(\mathrm{Mpa})\end{array}$ & Evaluation \\
\hline 2 & 23.60 & 20 & qualify \\
\hline 4 & 21.80 & 20 & qualify \\
\hline 6 & 20.57 & 20 & qualify \\
\hline 8 & 20.20 & 20 & qualify \\
\hline
\end{tabular}

Based on the concrete compressive that has been studied can be concluded that the use of Sinabung's volcanic ash as a substitute for cement in concrete mixture has the same strength with normal concrete but with a more affordable price of cement material thus construction costs can be reduced.

\section{CONCLUSION}

There are several conclusions obtained in this study, including:

The slump value increased for the composition of volcanic ash $4 \%$, while above $4 \%$ slump value decreased.

The addition of Sinabung's volcanic ash of $4 \%$ produces the compressive strength of concrete near the normal concrete.
Replacement of cement with volcanic ash produces a lower concrete compression load than normal concrete for the life of concrete below 14 days, while for 28 days concrete time yields higher compressive strength value than normal concrete in concrete mixture with $2 \%$ and 4 $\%$ of volcanic ash. Likewise, the addition of $6 \%$ and $8 \%$ volcanic ash yielded concrete compressive strength values close to equal to the compressive strength of normal concrete. Thus it can be stated that volcanic ash has the potential to replace part of the amount of cement in the concrete mixture. The addition of volcanic ash shows improvement of compression strength of concrete, in specific cement replacement ratio. It can be stated that volcanic ash has the potential to replace part of the amount of cement in the concrete mixture.

The use of Sinabung's volcanic ash as a substitute for cement in concrete mixture has the same strength with normal concrete but with a more affordable price of cement material thus construction costs can be reduced. It is important that used materials are locally accessible and environmentally friendly materials. This is a example of sustainable development in construction industry. Creating of new concrete products, and new constructions, but at a same time decrease production of cement, by using available replacement.

\section{ACKNOWLEDGEMENTS}

The authors would like to thank the head and the technicians of the Laboratory of Institut Teknologi Medan for their help during the experimental work. Great appreciation is also given to Ministry of Research, Technology and Higher Education of the Republic of Indonesia for the financial support.

\section{REFERENCES}

1. Bayuaji, R., Darmawan, M. R., Pudji, I., \& Husin, N. A. (2011). Characteristic of pozzolanicity Bromo's volcanic ash. Proceedings of International Seminar on Applied Technology, Science, and Arts. Surabaya, Indonesia, (pp : 218-223).

2. Tsado, T. Y., Yewa, M., Yaman, S., \& Yewa, F. (2014). Comparative analysis of properties of some artificial pozzolana in concrete production. International Journal of Engineering and Technology, 4(5), 251-255.

3. Olawuyi, B. J., \& Olusola, K. O. (2010). Compressive strength of volcanic ash/ordinary portland cement laterized concrete. Civil Engineering Dimension, 12(1), 23-28.

4. Latif, D. O., Rifa'i, A., \& Suryolelono, K. B. (2016). Effect of Kelud volcanic ash utilization on the physical properties as stabilizer material for soil stabilization. Electronic Journal of Geotechnical Engineering, 20(26), 1679-1687. 
5. Reddy, M. V. S., Ashalatha, K., \& Surendra, K. (2016). Studies on eco-friendly concrete by partial replacement of cement with alccofine and fine fly ash. ARPN Journal of Engineering and Applied Sciences, 11(5), 3445-3448.

6. Fathi, A., Shafiq, N., Nuruddin, M. F., \& Elheber A. (2013). Study the effectiveness of the different pozzolanic material on self-compacting concrete. ARPN Journal of Engineering and Applied Sciences, 8(4), 299-305.

7. Tumingan, M., Tjaronge, W., Djamaluddin, R., \& Sampebulu, V. (2014). Compression strength of concrete with pond ash as replacement of fine aggregate. ARPN Journal of Engineering and Applied Sciences, 9(12), 2923-2928.

8. Latif, D. O., Rifa'i, A., \& Suryolelono, K. B. (2017) Impact of volcanic ash and lime adding on expansive soil for subgrade layer. International Review of Civil Engineering (I.RE.C.E.), 8(5), 255-260.

9. Latif, D. O., Rifa'i, A., \& Suryolelono, K. B. (2016) Chemical characteristics of volcanic ash in Indonesia for soil stabilization: morphology and mineral content. International Journal of GEOMATE, 11(26), 2606-2610.
10. Waruwu, A., Hardiyatmo, H. C., \& Rifa'i, A., (2017). Deflection behavior of the nailed slab system-supported embankment on peat soil. Journal of Applied Engineering Science, 15(4), 556-563.

11. Waruwu, A, Maulana, \& Halim, H., (2017). Settlement estimation of peat reinforced with bamboo grid under embankment. International Review of Civil Engineering (I.RE.C.E.), 8(6), 299-306.

12. Curović, N. (2017). Recycled concrete - ecology and economic criterias. Journal of Applied Engineering Science, 15(4), 271-274.

13. Susanti, R. D., Maulana, Waruwu, A. (2017). Bearing capacity improvement of peat soil by preloading. ARPN Journal of Engineering and Applied Sciences, 12(1), 121-124. 